\title{
Assessing and Encouraging Progressivity of Post-Mining Activities Arrangements in Indonesia
}

\author{
Sigit Wibowo *), Lita Tyesta ALW**), Kornelius Benuf**) \\ *) Faculty of Law, Universitas Diponegoro, email: \\ sigitwibowo@students.undip.ac.id \\ $\left.{ }^{* *}\right)$ Faculty of Law, Universitas Diponegoro, email: litatyesta.undip@yahoo.com \\ ${ }^{* * *}$ Faculty of Law, Universitas Diponegoro, Email: korneliusbenuf@gmail.com
}

\begin{abstract}
Mineral and coal mining activities have an impact on environmental damage. So that to overcome the environmental damage, a policy is made regarding postmining activities. In essence, post-mining activities are an effort to restore the functions of the natural environment and social functions and are adjusted to local conditions in the mining area. However, the policy that was previously regulated in the old Mineral and Coal Law has not been effectively implemented. The existence of regulations regarding post-mining activities in the new Mineral and coal Law is expected to be more progressive. The problem is how is the progress of regulations regarding post-mining activities in the new Mineral and Coal Law? This problem will be examined in this paper using normative juridical research methods. Based on the research results, it is concluded that there is no progressive regulation of post-mining activities in the new Minerba Law, so it is necessary to have progressive regulations regarding post-mining activities in the future.
\end{abstract}

Keywords: Progressive, Activities, Post-mining, Mineral and Coal

\section{Introduction}

In essence, based on the goal of the Republic of Indonesia, namely "to protect the entire Indonesian nation and the entire homeland of Indonesia", as stated in paragraph 4 (fourth) of the Preamble to the 1945 Constitution of the Republic of Indonesia, the purpose of this state is to become the basis for implementing the 1945 Constitution of the Republic of Indonesia. Mineral and coal mining activities in Indonesia hereinafter referred to as Minerba. One of the realizations of the country's goals in Minerba mining activities is to regulate Post-mining activities. The purpose of regulating Post-mining activities is to ensure the return of natural environmental and social functions after Minerba mining activities are carried out ${ }^{1}$.

Regulation regarding post-mining activities is important, because it cannot be denied that Minerba mining activities not only bring positive impacts on the economic aspect, but on the other hand have negative impacts on environmental aspects ${ }^{2}$. This negative impact must be minimized as much as possible by making policies that require Minerba mining business actors to manage the land used for their mining operations, one of which is reforestation. This is done so that Minerba mining business actors are

\footnotetext{
1 Jeanne Darc Noviayanti Manik, 'Pengelolaan Pertambangan Yang Berdampak Lingkungan Di Indonesia', Promine, 1.1 (2013), 1-10. p.9.

2 Wiwik Harjanti, 'Upaya Alternatif Bagi Pemerintah Indonesia Dalam Mengurangi Dampak Negatif Kegiatan Pertambangan Di Indonesia', Risalah Hukum, 3.3 (2016), 44-52. p.49.
} 
responsible for environmental damage caused by their business activities, ${ }^{3}$ and if it is related to the goal of the Indonesian state, namely to protect all Indonesian people, the policy regarding post-mining activities is in accordance with the goals of the Indonesian state. The Indonesian state wants Minerba mining activities to increase economic growth while preserving the environment and the social interests of the Indonesian people.

Realizing economic growth by paying attention to environmental sustainability and the social interests of the Indonesian people in Minerba mining activities, based on the concept of sustainable development that has long been embraced by the Republic of Indonesia. The concept of sustainable development is essentially a long-term and sustainable development between generations, taking into account the balance between economic interests, community social interests and environmental interests. ${ }^{4}$ The most important element of the concept of sustainable development is balance, which means not prioritizing one and not ignoring the other. So that when brought into the context of Minerba mining activities in Indonesia, it is necessary to maintain a balance between economic progress, social interests of the community and environmental sustainability.

The goals of the Indonesian state and the concept of sustainable development in Minerba mining business activities are concreted by the existence of regulations regarding post-mining activities. Due to the amendment to "Law Number 4 of 2009 concerning Mineral and Coal Mining", hereinafter referred to as the old Minerba Law, to Law Number 3 of 2020 hereinafter referred to as the new Minerba Law, in which the regulation regarding post-mining activities also underwent changes., it is necessary to know whether the change in regulation is in accordance with the needs of the community or not, in accordance with the goals of the Indonesian state and the concept of sustainable development or not. At the practical level in Indonesia, mining companies often neglect Minerba mining companies, on lands that were ex-mining operations, a concrete example of which can be seen in the following figure:

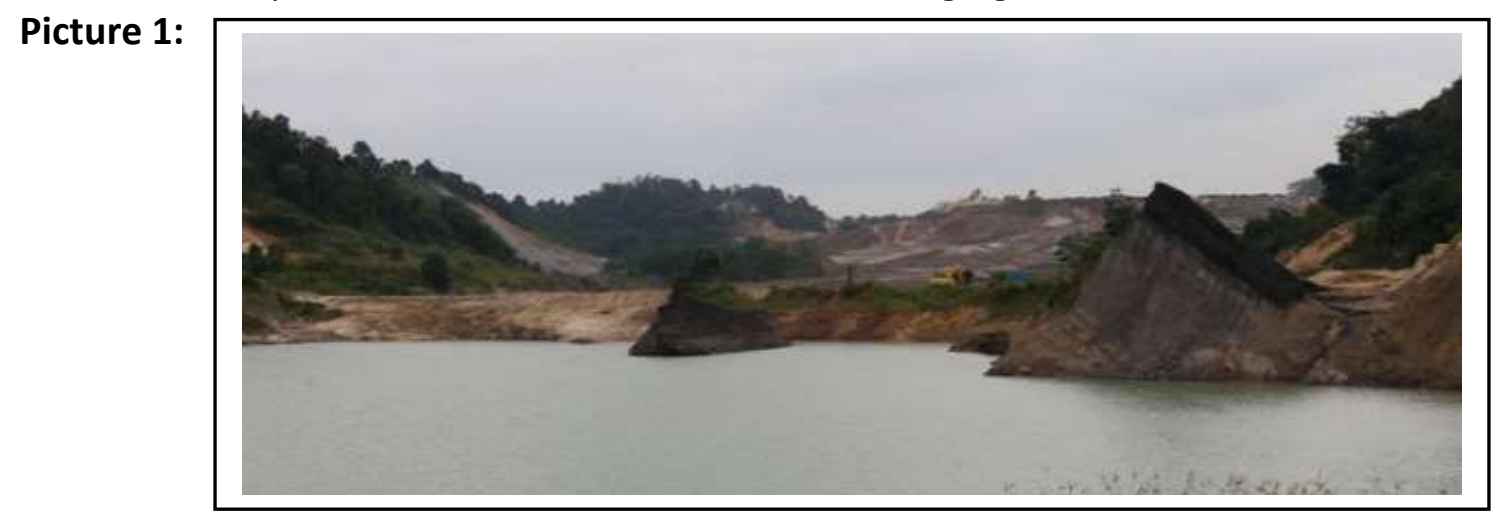

Source: $C N N$ Indonesia ${ }^{5}$

\footnotetext{
3 Fenty U Puluhulawa, 'Pengawasan Sebagai Instrumen Penegakan Hukum Pada Pengelolaan Usaha Pertambangan Mineral Dan Batubara', Jurnal Dinamika Hukum, 11.2 (2011), 306-315. p.312.

${ }^{4}$ Andri Gunawan Wibisana, 'Pembangunan Berkelanjutan: Status Hukum Dan Pemaknaannya', Jurnal Hukum \& Pembangunan, 43.1 (2013), 54-90 <https://doi.org/10.21143/jhp.vol43.no1.1503>. p.59.

${ }^{5}$ Rosmiyati Dewi Kand iva Dessthania Suastha, 'KLHK: Tambang Ciptakan "Kota Hantu"', CNN Indonesia, 2016.
} 
The picture above is a former mine from the Minerba mining company in the Makroman area, Samarinda Ilir, East Kalimantan. The condition of the Minerba ex-mining land that was left by the mining company is clear evidence of the Minerba mining company's neglect of its ex-mining excavated land, and is a form of violation of the regulations regarding post-mining activities in the Minerba Law. Departing from this description, this paper will examine more deeply how is the progress of regulating post-mining activities in the new Mining Law?

\section{Research Method}

The research method used is normative juridical, ${ }^{6}$ by comparing the progressivity of the regulation regarding post-mining activities between the old Mining Law and the new Mining Law, for later analysis. The data used is secondary data, ${ }^{7}$ in the form of primary legal materials, namely statutory regulations (new and old Minerba Laws) and secondary legal materials, namely books and journals related to the discussion of this research. Secondary collection is done through literature study.$^{8}$ The analytical method used is comparative juridical, which is a method of analysis by comparing one statutory regulation with other statutory regulations.

\section{Research and Discussion}

\subsection{Interpreting Progressive Legislation}

Discussions about the progressivity of laws and regulations cannot be separated from legal politics. Legal politics is an activity of choosing and the method to be used to achieve certain social and legal goals in society. ${ }^{9}$ Legal politics contains three basic things, namely state policies regarding laws that will be enforced in order to achieve state goals, political, economic, social, cultural background for the birth of legal products, and law enforcement in society. ${ }^{10}$ The social goals of the Indonesian people are the same as the goals of the Indonesian state as stated in paragraph 4 (fourth) of the Preamble to the 1945 Constitution of the Republic of Indonesia. Returning to the discussion on the Progressivity of laws and regulations, it can be interpreted simply that these laws and regulations must base on progressive law.

Progressive laws will lead to people's happiness, but unfortunately in the era of modern society, especially modern society in Indonesia, its realization is very difficult. ${ }^{11}$ Modern society in Indonesia is characterized by the dominance of positive law, but positive law has created a wide gaping chasm between law and humanity. This makes the realization of progressive law in the era of modern society very difficult due to the dominance of

\footnotetext{
${ }^{6}$ Roni Hanitjo Soemitro, Metode Penelitian Hukum Dan Jurimetri (Jakarta: Ghalia Indonesia, 1982). p. 35.

7 Depri Liber Sonata, 'Metode Penelitian Hukum Normatif Dan Empiris Karakteristik Khas Dari Metode Meneliti Hukum', Fiat Justisia Jurnal IImu Hukum, 8.1 (2014), 15-35. p. 21.

${ }^{8}$ Kornelius Benuf and Muhamad Azhar, 'Metodologi Penelitian Hukum Sebagai Instrumen Mengurai Permasalahan Hukum Kontemporer', Gema Keadilan, 7.1 (2020), 20-33. p. 23.

${ }^{9}$ Satjipto Rahardjo, IImu Hukum, ed. by Awaludin Marwan, VIII (Bandung: Citra Aditya Bakti, 2014). p. 37.

${ }^{10}$ Moh Mahfud MD, Politik Hukum Di Indonesia, Cetakan ke (Jakarta: Pers, Rajawali, 2014). p. 34.

${ }^{11}$ Satjipto Rahardjo, 'Between Two Worlds: Modern State and Traditional Society in Indonesia', Law and Society Review, 28.3 (1994), 493-502. p. 498.
} 
legal positivism in modern Indonesian society. ${ }^{12}$ Progressive law is a way out of bureaucratic and procedural problems in law enforcement in today's modern society. Progressive law has 3 (three) basic assumptions, namely law for humans, law is never final and has the status of "law in the making", and law is not a technology without conscience. The criteria for progressive law are its goals to achieve human welfare and happiness, contain good human moral values, liberate both in practice and at the theoretical level, and are functionally critical, meaning that they will not stop making updates to respond to the times. ${ }^{13}$

The thought that underlies progressive law which is also its idealism is that "law is an institution that aims to deliver humans to a just, prosperous and happy life" ${ }^{14}$. The incarnation of progressive law in the laws and regulations in Indonesia must also be based on the idealism of progressive law. The development of progressive law, apart from being a response to bureaucratic and procedural problems in modern society, is also the driving force behind the development of progressive law, namely industrialization, capitalism and the bourgeoisie. ${ }^{15}$

Industrialization, capitalism and the bourgeoisie are real phenomena in modern society in Indonesia today. This phenomenon is a concretization of the economic orientation of modern society which prioritizes wealth and always tries to maintain and even always wants to increase its wealth. In order to maintain and develop this wealth, a law is made in the sense of legislation that can accommodate the interests of modern society, namely economic interests. ${ }^{16}$ Legislation that prioritizes economic interests will ignore moral and humanitarian aspects, the Act will only become a technology that has no conscience, ${ }^{17}$ This is in stark contrast to the idealism of progressive law, namely human welfare and happiness.

The relationship between the basic concepts of progressive legal thinking as described above in the laws and regulations is that the laws and regulations are a tool to describe the basic concepts of progressive legal thinking. This means that progressive laws and regulations must be able to deliver humans to a just, prosperous life and make humans happy. So if it is interpreted more specifically, that the arrangement of an article in progressive legislation, the article must be able to realize justice, welfare and human happiness.

\subsection{Assessing and Encouraging Progressivity of Post-Mining Activities Arrangements in Indonesia}

Continuing from the first discussion above, this section will explain in detail the progressivity of the regulation of post-mining activities in the new Mining Law. It is necessary to know together that the characteristics of the Minerba mining business are

\footnotetext{
12 Syofyan Hadi, 'Hukum Positif Dan The Living Law (Eksistensi Dan Keberlakuannya Dalam Masyarakat)', DIH: Jurnal Ilmi Hukum, 13.26 (2017), 259-266. p. 261.

${ }^{13}$ Satjipto Rahardjo, 'Hukum Progresif : Hukum Yang Membebaskan', Hukum Progresif, 1.1 (2005), 1-24. p. 45.

${ }^{14}$ Satjipto Rahardjo, Hukum Progresif (Yogyakarta: Genta Publishing, 2009). p. 32.

${ }^{15}$ Satjipto Rahardjo, Huk. Progresif. p. 35.

${ }^{16}$ Laurensius Arliman, 'Perlindungan Hukum UMKM Dari Eksploitasi Ekonomi Dalam Rangka Peningkatan Kesejahteraan Masyarakat', Jurnal RechtsVinding, 6.3 (2017), 387-402. p. 391.

17 Satjipto Rahardjo, Huk. Progresif. p. 37.
} 
non-renewable so that Minerba mining activities must be carried out by maintaining a balance between economic interests, social interests and environmental interests. ${ }^{18}$ The implementation of Minerba mining activities by taking into account the balance of 3 (three) interests, namely economic interests, social interests, and environmental interests, is in line with the concept of sustainable development that has been adopted by the Indonesian state in national development.

The national development of the Indonesian state is directed at achieving community welfare and sustainable development to realize a beautiful and sustainable Indonesia in line with the direction of environmental development as outlined in the Long-Term Development Plan (RPJP) for 200-2025. ${ }^{19}$ By accommodate the national development interests of the Indonesian state, which in essence is also in line with the concept of sustainable development as stipulated in the 1972 Stockholm Declaration, and is currently used as the basis for environmental management throughout the world, including in Indonesia. ${ }^{20}$ So that every activity that is considered to be damaging to environmental sustainability must be regulated in such a way so that environmental damage can be minimized.

Minerba mining activities are activities that damage environmental sustainability, ${ }^{21}$ so that these activities must be regulated so that the environmental damage caused can be minimized. One form of regulation on mining activities aimed at reducing environmental damage caused by Minerba mining activities is the regulation on Postmining Activities. Post-mining activities as regulated in Article 1 number 27 of the Minerba Law which just defines Post-mining Activities are;

"a planned, systematic, and continuing activity after as or all mining business activities to restore the function of the natural environment and social function according to local conditions throughout the mining area".

Post-mining activities aim to overcome environmental damage due to mining activities, by taking into account and absorbing the aspirations of the community around the Minerba mining operational area, without the support and participation of the community around Post-mining activities it will be difficult for Minerba mining companies to carry out, so that the regulation of Post-mining activities will not work effectively. ${ }^{22}$

Post-mining activities are important for all Minerba mining companies in Indonesia. However, in practice in Indonesia, not all Minerba mining companies carry out Postmining activities, in other words many Minerba mining companies violate their

\footnotetext{
18 Ahmad Redi, 'Dilema Penegakan Hukum Penambangan Mineral Dan Batubara Tanpa Izin Pada Pertambangan Skala Kecil', Jurnaal Rechtsvinding, 5.3 (2016), 399-420. p. 311.

19 Ahmad Jazuli, 'Dinamika Hukum Lingkungan Hidup Dan Sumber Daya Alam Dalam Rangka Pembangunan Berkelanjutan', Jurnaal Rechtsvinding, 4.2 (2015), 181-197. p. 185.

20 Fernando J. M. M. Karisoh Rodrigo Christopher Rembet, Flora Pricilla Kalalo, 'Pengaturan Hukum Pengelolaan Lingkungan Hidup Menurut Deklarasi Stockholm 1972', Lex Et Societatis, 8.4 (2020), 36-44. p. 41.

${ }^{21}$ IPG. Ardhana, 'Sinkronisasi Kegiatan Pertambangan Pada Kawasan Hutan', Jurnal Bumi Lestar, 9.2 (2009), 288-299. p. 291.

22 Dewan Perwakilan Rakyat, Naskah Akademik Rancangan Undang-Undang Tentang Perubahan Atas Undang-Undang Nomor 4 Tahun 2009 Tentang Pertambangan Mineral Dan Batubara (Jakarta, 2018). p. 59.
} 
obligations to carry out Post-mining activities as regulated in the Minerba Law. ${ }^{23}$ In addition to what has been mentioned in the introduction regarding the example of the Minerba mining company neglecting its ex-mining excavated land, which was carried out by the Minerba Mining company in the Makroman area, Samarinda Ilir, East Kalimantan, the following are some examples of other cases which are violations of the Minerba company's obligation to carry out its obligation to carry out Post-mining Activities;

\subsubsection{Former Mine in Sirise, East Manggarai Regency}

The first example is the result of research conducted by the "Research Center for Politics and Government (PolGov), UGM Department of Politics and Government released in a discussion held in Kupang in 2016". Based on this research, it is known that the local community is not involved in granting approval for the Minerba mining activity, and after the Coal contained in the area has been excavated and taken by the company, the Minerba Mining company does not carry out its obligations to carry out Post-Mining Activities as regulated in the Minerba Law. ${ }^{24}$

The following is a picture of the appearance of a former mine in Sirise, East Manggarai Regency.

\section{Picture II:}

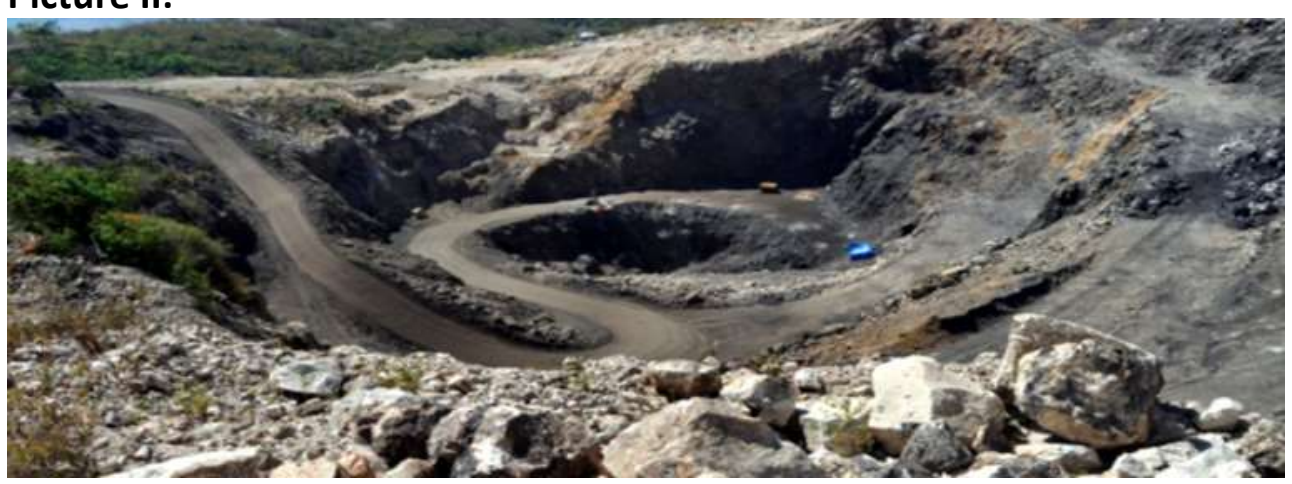

Source: Floresa.co

\subsubsection{Abandonment of Ex-Mining Land by Minerba Mining Company in Samarinda}

Another example of a violation of the provisions regarding post-mining activities by a mining company Minerba occurred in Samarinda, East Kalimantan. The Minerba Mining Company does not carry out post-mining activities, ${ }^{25}$ as stipulated in the Minerba Law. The appearance of the former mining area of the company is as follows.

\footnotetext{
${ }^{23}$ Rakyat. p. 32.

${ }^{24}$ Ari Dwi, 'Riset UGM: Terjadi Peminggiran Masyarakat Lokal Dalam Tata Kelola Tambang Di NTT', Floreza.Co, 2016. p. 89.

${ }^{25}$ Humas Prov Kalimantan Timur, 'Pertambangan Batu Bara Banyak Merusak Lingkungan', Pemerintah Provinsi Kalimantan Timur, 2018. p. 76.
} 
Picture III:

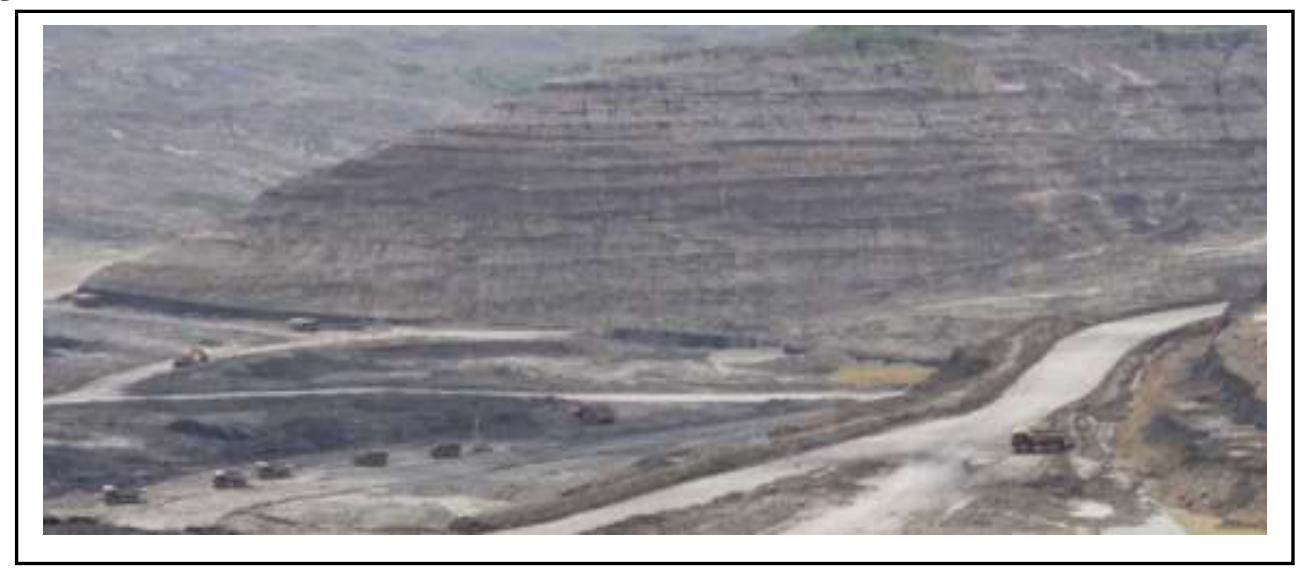

Source: Dokumentasi Pemerintah Provinsi Kalimantan Timur

Based on the explanation above regarding the importance of implementing post-mining activities, for the return of environmental functions and environmental sustainability and the realization of sustainable development. However, the empirical fact is that in Indonesia many Minerba mining companies do not carry out their obligations to carry out these post-mining activities, as the examples stated above. This shows that the regulation regarding Post-mining activities in the Minerba Mining Law has not been effective.

The changes to the old Mining Law on Mineral and Coal Mining into the new Mining Law are aimed at making the new Law effective. Even in the general explanation of the new Mining Law, it is stated that the new Mining Law is a refinement of the old Mining Law, there are new content materials added to the new Mining Law, one of which is "strengthening policies related to environmental management in Mining business activities, including the implementation of Reclamation and Post-mining". However, if one examines and compares the regulations regarding post-mining activities, there is not a single difference between the old Mining Law and the new Mining Law.

If an analysis is carried out regarding the progressiveness of the regulation of postmining activities in the new Mining Law, the criteria for the regulation can be said to be progressive if it can lead the Indonesian people to a just, prosperous life and make the Indonesian people happy. After researching and comparing the contents of the regulation regarding Post-mining activities in the new Mining Law and the old Mining Law, there is no difference. This shows that there is no progressiveness in the regulation of post-mining activities in the new Minerba Law. The absence of progressivity in the regulation of Post-mining activities will make environmental problems due to Minerba mining activities unable to be minimized which in the end will make the Indonesian people suffer and are far from prosperous, and make the Indonesian people unhappy. Changes in regulations regarding post-mining activities by animating the concept of progressive law is an absolute must. So that in the future, Minerba mining activities can create a just and prosperous life for the Indonesian people, and can realize sustainable development in Indonesia. It is the concept of progressive law that will lead the Indonesian people towards their goal of realizing a just and prosperous Indonesian society. 


\section{Clossing}

Based on the discussion above, it can be concluded that progressive laws and regulations will lead to a just, prosperous and happy life for the Indonesian people. When the concept of progressive law is used as an instrument to measure the progressivity of regulation regarding post-mining activities in the new Mining Law, it is known that there is no progressiveness of regulation of post-mining activities in the new Mining Law, this will greatly damage the environment and will suffer the people and This will further distance the Indonesian people from their ideals of realizing a just and prosperous society. So it is necessary to change the regulation regarding more progressive postmining activities in the future.

\section{References}

\section{Journal}

[1] Ahmad Redi, 'Dilema Penegakan Hukum Penambangan Mineral Dan Batubara Tanpa Izin Pada Pertambangan Skala Kecil', Jurnaal Rechtsvinding, 5.3 (2016), 399420

[2] Arliman, Laurensius, 'Perlindungan Hukum UMKM Dari Eksploitasi Ekonomi Dalam Rangka Peningkatan Kesejahteraan Masyarakat', Jurnal RechtsVinding, 6.3 (2017), 387-402

[3] Benuf, Kornelius, and Muhamad Azhar, 'Metodologi Penelitian Hukum Sebagai Instrumen Mengurai Permasalahan Hukum Kontemporer', Gema Keadilan, 7.1 (2020), 20-33

[4] Depri Liber Sonata, 'Metode Penelitian Hukum Normatif Dan Empiris Karakteristik Khas Dari Metode Meneliti Hukum', Fiat Justisia Jurnal IImu Hukum, 8.1 (2014), 15-35

[5] IPG. Ardhana, 'Sinkronisasi Kegiatan Pertambangan Pada Kawasan Hutan', Jurnal Bumi Lestar, 9.2 (2009), 288-99

[6] Jazuli, Ahmad, 'Dinamika Hukum Lingkungan Hidup Dan Sumber Daya Alam Dalam Rangka Pembangunan Berkelanjutan', Jurnaal Rechtsvinding, 4.2 (2015), 181-97

[7] Jeanne Darc Noviayanti Manik, 'Pengelolaan Pertambangan Yang Berdampak Lingkungan Di Indonesia', Promine, 1.1 (2013), 1-10

[8] Puluhulawa, Fenty U, 'Pengawasan Sebagai Instrumen Penegakan Hukum Pada Pengelolaan Usaha Pertambangan Mineral Dan Batubara', Jurnal Dinamika Hukum, 11.2 (2011), 306-15

[9] Rodrigo Christopher Rembet, Flora Pricilla Kalalo, Fernando J. M. M. Karisoh, 'Pengaturan Hukum Pengelolaan Lingkungan Hidup Menurut Deklarasi Stockholm 1972', Lex Et Societatis, 8.4 (2020), 36-44

[10] Satjipto Rahardjo, 'Between Two Worlds: Modern State and Traditional Society in Indonesia', Law and Society Review, 28.3 (1994), 493-502

[11] _- - 'Hukum Progresif : Hukum Yang Membebaskan', Hukum Progresif, 1.1 (2005), 1-24

[12] Syofyan Hadi, 'Hukum Positif Dan The Living Law (Eksistensi Dan Keberlakuannya Dalam Masyarakat)', DIH: Jurnal IImi Hukum, 13.26 (2017), 259-66

[13] Wibisana, Andri Gunawan, 'Pembangunan Berkelanjutan: Status Hukum Dan 
Pemaknaannya', Jurnal Hukum \& Pembangunan, 43.1 (2013), 54-90 <https://doi.org/10.21143/jhp.vol43.no1.1503>

[14] Wiwik Harjanti, 'Upaya Alternatif Bagi Pemerintah Indonesia Dalam Mengurangi Dampak Negatif Kegiatan Pertambangan Di Indonesia', Risalah Hukum, 3.3 (2016), 44-52

\section{Books}

[1] MD, Moh Mahfud, Politik Hukum Di Indonesia, Cetakan ke (Jakarta: Pers, Rajawali, 2014)

[2] Satjipto Rahardjo, Hukum Progresif (Yogyakarta: Genta Publishing, 2009)

[3] Satjipto Rahardjo, IImu Hukum, ed. by Awaludin Marwan, VIII (Bandung: Citra Aditya Bakti, 2014)

[4] Roni Hanitjo Soemitro, Metode Penelitian Hukum Dan Jurimetri (Jakarta: Ghalia Indonesia, 1982)

[5] Rakyat, Dewan Perwakilan, Naskah Akademik Rancangan Undang-Undang Tentang Perubahan Atas Undang-Undang Nomor 4 Tahun 2009 Tentang Pertambangan Mineral Dan Batubara (Jakarta, 2018)

[6] Timur, Humas Prov Kalimantan, 'Pertambangan Batu Bara Banyak Merusak Lingkungan', Pemerintah Provinsi Kalimantan Timur, 2018

[7] Iva Dessthania Suastha, Rosmiyati Dewi Kand, 'KLHK: Tambang Ciptakan "Kota Hantu"', CNN Indonesia, 2016

[8] Dwi, Ari, 'Riset UGM: Terjadi Peminggiran Masyarakat Lokal Dalam Tata Kelola Tambang Di NTT', Floreza.Co, 2016 